\title{
The Effect of Irrigation Rate on the Water Relations of Young Citrus Trees in High-Density Planting
}

\author{
Said A. Hamido *(D) and Kelly T. Morgan \\ Southwest Florida Research and Education Center, University of Florida, 2685 SR 29 N, \\ Immokalee, FL 34142, USA; conserv@ufl.edu \\ * Correspondence: shamido@ufl.edu
}

check for updates

Citation: Hamido, S.A.; Morgan, K.T. The Effect of Irrigation Rate on the Water Relations of Young Citrus Trees in High-Density Planting.

Sustainability 2021, 13, 1759.

https://doi.org/10.3390/su13041759

Received: 15 January 2021

Accepted: 3 February 2021

Published: 6 February 2021

Publisher's Note: MDPI stays neutral with regard to jurisdictional claims in published maps and institutional affiliations.

Copyright: (c) 2021 by the authors. Licensee MDPI, Basel, Switzerland. This article is an open access article distributed under the terms and conditions of the Creative Commons Attribution (CC BY) license (https:// creativecommons.org/licenses/by/ $4.0 /)$.

\begin{abstract}
The availability and proper irrigation scheduling of water are some of the most significant limitations on citrus production in Florida. The proper volume of citrus water demand is vital in evaluating sustainable irrigation approaches. The current study aims to determine the amount of irrigation required to grow citrus trees at higher planting densities without detrimental impacts on trees' water relation parameters. The study was conducted between November 2017 and September 2020 on young sweet orange (Citrus sinensis) trees budded on the 'US-897' (Cleopatra mandarin $x$ Flying Dragon trifoliate orange) citrus rootstock transplanted in sandy soil at the Southwest Florida Research and Education Center (SWFREC) demonstration grove, near Immokalee, Florida. The experiment contained six planting densities, including 447, 598, and 745 trees per ha replicated four times, and 512, 717, and 897 trees per ha replicated six times. Each density treatment was irrigated at $62 \%$ or $100 \%$ during the first 15 months between 2017 and 2019 or one of the four irrigation rates $(26.5,40.5,53$, or $81 \%$ ) based on the calculated crop water supplied (ETc) during the last 17 months of 2019-2020. Tree water relations, including soil moisture, stem water potential, and water supplied, were collected periodically. In addition, soil salinity was determined. During the first year (2018), a higher irrigation rate $(100 \% \mathrm{ETc})$ represented higher soil water contents; however, the soil water content for the lower irrigation rate $(62 \%$ ETc) did not represent biological stress. One emitter per tree regardless of planting density supported stem water potential $\left(\Psi_{\text {stem }}\right)$ values between -0.80 and $-0.79 \mathrm{MPa}$ for lower and full irrigation rates, respectively. However, when treatments were adjusted from April 2019 through September 2020, the results substantially changed. The higher irrigation rate $(81 \% \mathrm{ETc})$ represented higher soil water contents during the remainder of the study, the lower irrigation rate $\left(26.5 \%\right.$ ETc) represents biological stress as a result of stem water potential ( $\left.\Psi_{\text {stem }}\right)$ values between -1.05 and $-0.91 \mathrm{MPa}$ for lower and higher irrigation rates, respectively. Besides this, increasing the irrigation rate from $26.5 \%$ to $81 \%$ ETc decreased the soil salinity by $33 \%$. Although increasing the planting density from 717 to 897 trees per hectare reduced the water supplied on average by $37 \%$ when one irrigation emitter was used to irrigate two trees instead of one, applying an $81 \%$ ETc irrigation rate in citrus is more efficient and could be managed in commercial groves.
\end{abstract}

Keywords: irrigation rate; water supplied; stem water potential; soil moisture content; planting density; soil salinity

\section{Introduction}

Sustainable irrigation practices in irrigated crops are crucial crop production management decisions in Florida sandy soils. One of the most encouraging strategies for achieving this objective might be reducing water volumes during certain stages of crop development [1]. A deficit in water or fertilizers in an active growth stage could decrease tree yield and fruit quality. The severity of deficit irrigation on trees depends on the fruit growth stage [2]. Deficit irrigation during the first and second stages of fruit maturity has no significant effect on yield [3]; however, during the third stage it reduces fruit size [4,5]. Earlier studies have reported that plant water use in the third stage was determined to be 
considerably greater than that in the second stage [6], with an estimated value of around $120 \%$ of the evapotranspiration rate (ET). Thus, an accurate evaluation of crop water demands (irrigation amount and timing) during the growth period can maximize the crop yield and lower water losses and crop stress [7].

Improving irrigation management approaches necessitates a proper understanding of crop water use and physiological responses under deficit irrigation conditions. Numerous studies have monitored the citrus physiological response to different irrigation volumes utilizing plant water stress measures including stomatal conductance $[8,9]$ and the midday stem water potential [10-13]. The midday stem water potential $\left(\Psi_{\text {stem }}\right)$ is affirmed as one of the most steady, dependable, and accurate plant water indicators for irrigated crops $[14,15]$. Irrigation scheduling based on soil moisture and plant water condition sensors can improve crop water productivity and enhance water conservation practices. Soil sensors can also provide information on when to restart irrigation after precipitation events by interpreting the soil water depletion rate. Recommended optimum irrigation scheduling was recommended at allowable soil water depletion in the root zone, around $20 \%$ of field capacity [16].

Volumetric soil water content measurements have long been used for irrigation management [17-22]. Capacitance sensors linked with data-logger systems can be used to provide continuous measurements of volumetric water contents in real-time and facilitate accurate irrigation times and volumes to irrigate crops according to their water demands [23-26]. The sensors can inform growers when to provide irrigation and monitor the real-time soil moisture contents [27]. Thus, the use of sensors is critical for scheduling irrigation and maximizing the water supply efficiency in irrigated plants.

Sustainable irrigation approaches in the water-scarce era aim at reducing water losses and maximizing water productivity. The irrigation demands of citrus trees differ with climatic conditions, soil type, and cultivar [28]. Less rainfall normally results in greater irrigation demands; however, even in a remarkably wet year, noteworthy irrigation may be required due to sporadic rainfall distribution in subtropical climate regions, including Florida [29,30]. Supplemental irrigation is necessary to improve citrus yield [25].

Crop evapotranspiration (ETc) and crop coefficient estimates $(\mathrm{Kc})$ are the fundamental steps for improving crop water productivity [31]. FAO-56 Penman-Monteith, a major procedure, was broadly approved in measuring crop evapotranspiration (ETc) with a single crop coefficient $(\mathrm{Kc})$ [32]. Several researchers have published a wide range of seasonal crop coefficients in citrus trees estimated between 0.30 and 1.25 [33-35]. Besides this, annual citrus evapotranspiration is estimated to be $1143 \mathrm{~mm}$ and the citrus annual irrigation requirement is estimated to be between 381 and $432 \mathrm{~mm}$ depending on precipitation and distribution [36]. Determining a sustainable irrigation method requires developing a sufficient time for irrigation requirements for young citrus trees. In the previous publication of the research in this series, we demonstrated that an irrigation rate of $81 \%$ ETc significantly improved citrus tree growth and root development [37]. Investigating the decreased irrigation water application effect on young citrus tree water relations at higher densities has not been studied in Florida. Thus, a field-scale investigation in the current study was performed to determine if the current citrus irrigation practices need to be revised with different citrus planting densities.

Understanding the impact of different irrigation rates on citrus trees' water relation parameters is crucial for their sustainable management under conditions of limited water resources. Thus, the objectives were to determine the amount of irrigation required to grow young citrus trees at different planting densities and determine the water supply influence on water relation parameters, including the stem water potential of young citrus trees and soil moisture content in addition to soil salinity. 


\section{Materials and Methods}

\subsection{Site Description and Experimental Setup}

The project was conducted between November 2017 and September 2020 on 'Valencia' (Citrus sinensis) trees budded on the 'US-897' (Cleopatra mandarin x Flying Dragon trifoliate orange) citrus rootstock located at the University of Florida, Southwest Florida Research and Education Center (SWFREC) demonstration grove located at Immokalee, FL, USA (lat. $26.42^{\circ} \mathrm{N}$, long. $81.42^{\circ} \mathrm{W}$ ) [37]. Citrus trees were planted in Immokalee fine sandy soil (sandy, siliceous, hyperthermic Arenic Alaquods) in November 2017 at different planting densities (Table 1).

Table 1. Planting densities, tree spacings, number of rows per plot, and number of trees per row from November 2017 through September 2020 at the experimental grove at the Southwest Florida Research and Education Center (SWFREC).

\begin{tabular}{ccccc}
\hline $\begin{array}{c}\text { Planting Density } \\
\text { (Trees ha }{ }^{-1} \text { ) }\end{array}$ & $\begin{array}{c}\text { Tree Spacing (Space within Row } \\
\text { ' } \mathbf{m}^{\prime} \text { * Space between Rows ' } \mathbf{m} \text { ') }\end{array}$ & $\begin{array}{c}\text { Number of Rows } \\
\text { Per Plot }\end{array}$ & $\begin{array}{c}\text { Number of Trees } \\
\text { Per Row }\end{array}$ & $\begin{array}{c}\text { Number of } \\
\text { Replications }\end{array}$ \\
\hline 447 & $3.05 \times 7.32$ & 2 & 9 & 4 \\
512 & $4.27 \times 4.57$ & 3 & 6 & 6 \\
598 & $2.29 \times 7.32$ & 2 & 12 & 4 \\
717 & $3.05 \times 4.57$ & 3 & 9 & 6 \\
745 & $1.83 \times 7.32$ & 2 & 15 & 4 \\
897 & $2.44 \times 4.57$ & 3 & 11 & 6 \\
\hline
\end{tabular}

The experiment comprised of five $165 \mathrm{~m}$-long blocks. Each block contained six plots; each plot was $\approx 27 \mathrm{~m}$ long and $7.4 \mathrm{~m}$ or $9.2 \mathrm{~m}$ wide for two-row or three-row blocks, respectively. Three planting densities in two-row blocks presenting 447, 598, and 745 trees per ha were replicated four times each, and three planting densities in three-row blocks presenting 512, 717, and 897 trees per ha were replicated six times. Each density row was watered to supply $62 \%$ or $100 \%$ of the crop water supplied (ETc) recommended by the Citrus Irrigation App for young citrus trees during the first 15 months (January 2018-March 2019), then adjusted according to the daily soil moisture reading from soil sensors due to the higher soil moisture contents. Trees were irrigated daily to keep the soil moisture contents above $80 \%$ of field capacity at least for the higher irrigation rates under the current study, and the irrigation schedule from the Citrus Irrigation App was determined every two weeks. Irrigation schedules (time for irrigation) were adjusted by adding or subtracting minutes from the citrus irrigation app estimates based on the daily soil moisture sensors measurements. Irrigation rates were divided into four irrigation treatments from April 2019 through the remainder of the project to provide $26.5 \%, 40.5 \%, 53 \%$, or $81 \%$ of daily ETc (more details are presented in the first publication of this series) [37] based on the Citrus Irrigation App using data from the Florida Automated Weather Network (FAWN, http:/ / fawn.ifas.ufl.edu/tools/irrigation/citrus/scheduler/) station located about $100 \mathrm{~m}$ away from the demonstration site at SWFREC. The irrigation was divided into three irrigation schemes, each satisfying two plots (two replications) within the block.

Trees were watered using the 360-degree micro-sprinkler (Maxijet Inc., Dundee, FL, USA), with one emitter per one tree placed $\approx 33 \mathrm{~cm}$ from the trunk for tree densities at 447 , 512,598 , and 717 trees per ha or between two trees for 745 and 897 trees per ha to meet the proposed irrigation treatment at different flow rates. Irrigation was provided with a $172 \mathrm{KPa}$ pressure pump to wet a circular area of the soil surface with $3.6 \mathrm{~m}$ diameter per soil surface. Irrigation was halted during precipitation events greater than $17 \mathrm{~mm} \mathrm{day}^{-1}$ during summer seasons during the experimentation period.

\subsection{Meteorological Measurements}

In the current study, irrigation was programmed in keeping with calculated crop evapotranspiration, ETc, determined with a single crop coefficient procedure [32]. Reference FAO Penman-Monteith evapotranspiration (ETo) was acquired from the FAWN station located within $100 \mathrm{~m}$ from the experimental grove. Thus, the estimated Kc was calculated 
from the water supply data (ETc) presented in this paper and FAWN from November 2017 to August 2020. Crop coefficient (Kc) estimates were performed using Equation (1):

$$
\mathrm{Kc}=\mathrm{ETc} / \mathrm{ETo} .
$$

\subsection{Water Relations}

\subsubsection{Soil Moisture Contents}

In the current study, the soil water contents were determined using ECH2O 5TE soil sensors (Meter Environment, Pullman, WA) every 30 min from April 2018 to August 2020 for each treatment at 15,30 , and $45 \mathrm{~cm}$ soil depth to monitor the soil water movement and water percolation below the root zone. Sixty ECH2O 5TE soil sensors were connected with 12 EM-50G data loggers (Meter Environment, Pullman, WA). All the sensors were calibrated for volumetric soil water content using soil samples collected after the installation [38] of data loggers on 17 April 2018.

\subsubsection{Stem Water Potential}

The stem water potential ( $\left.\Psi_{\text {stem }}\right)$ was examined during May, August, and November of 2018 and 2019 and September 2020, as described by Hamido et al. [10], using a Portable Plant Water Status Console (Soil moisture Equipment Corp, Model 3115, Santa Barbara, CA). The stem water potential was determined on fully expanded sun-exposed matured leaves between 12:00 and 14:00. Three exemplary leaves per tree (two trees per sub-plot) were randomly chosen $24 \mathrm{~h}$ before the determinations and coated with a plastic and aluminum foil to enable the water potential of leaves and stems to be balanced. A razor-sharp cutter was utilized to crop leaf petioles nearby to the stem and set into the pressure chamber instantly to evade any changes. Then, the pressure was increased at $1 \mathrm{MPa} / 30 \mathrm{~s}$ using condensed nitrogen till the outflow of water was visible.

\subsection{Chemical Analysis}

\subsubsection{Irrigation Water Quality}

Duplicate water samples were collected from the irrigation well at the main pump during August 2018 and 2019. Water electrical conductivity (EC) and total dissolved solids (TDS) were obtained using an electrical conductivity meter (AB 30, Fisher Scientific, Pittsburgh, PA).

\subsubsection{Soil Salinity (EC)}

In October 2018 and May 2020, soil samples were collected from the demonstration grove by taking three soil samples per depth $(0-15,15-30$, and $30-45 \mathrm{~cm})$ from each sub-plot (60), then they were mixed and a sub-sample was chosen from each depth at different irrigation treatments. The EC of the soil extracts was found using the soil paste method recommended by Hanlon et al. [39]. A total of $20 \mathrm{~g}$ of moist soil samples was placed in a $100 \mathrm{~mL}$ cup and $40 \mathrm{~mL}$ of distilled water was added. The water-soil solution was stirred, allowed to equilibrate for four hours, filtered through Whatman no. 42 filter paper, then the soil salinity $(\mathrm{EC})$ was measured with an electrical conductivity meter (model AB30; Fisher Scientific, Hampton, NH) in $\mu \mathrm{S} \mathrm{cm}^{-1}$.

\subsection{Experimental Design and Statistical Analysis}

This experiment was carried out as a factorial of $2(62 \%$ or $100 \%$ ETc) or $4(26.5 \%$, $40.5 \%, 53 \%$, or $81 \%$ ETc) irrigation treatments $\times 6$ planting densities $(447,512,598,717,745$, or 897 trees per ha) in a complete randomized block design. Treatments were replicated at least four times. Data were analyzed using the appropriate Statistical Analysis System (SAS for Windows, Ver. 9.4, SAS Institute Inc., Cary, NC). All the measures collected at the three depths including soil moisture contents were not independent and were analyzed as a repeated measure. The analysis of variance (ANOVA) was employed to determine treatment effects on the measured stem water potential and yearly soil salinity. Statistical 
differences among means were plotted using the general linear model procedure (PROC GLM). The least significant difference test (LSD) was used to segregate the mean of the main effect at $p<0.05$.

\section{Results and Discussion}

\subsection{Meteorological Conditions}

Evapotranspiration (ET) is a major determinant in the water cycle for most crops, including citrus; hence, it plays a vital role in irrigation management $[20,29]$. The average daily reference evapotranspiration (ETo) rose by almost three times, from 1.5 to $4.3 \mathrm{~mm}$ day $^{-1}$ during December and July, respectively. Furthermore, the precipitation was not consistent during the same session. The cumulative monthly precipitation increased more than 12-fold from $24 \mathrm{~mm}$ to $300 \mathrm{~mm}$ during November 2017 and August 2019, respectively (Figure 1). However, in 2020 through to the end of September there was a cumulative precipitation of $1003 \mathrm{~mm}$, whereas 2019 had a higher annual precipitation than 2020 (1371 mm) while 2018 had only $1197 \mathrm{~mm}$ precipitation.

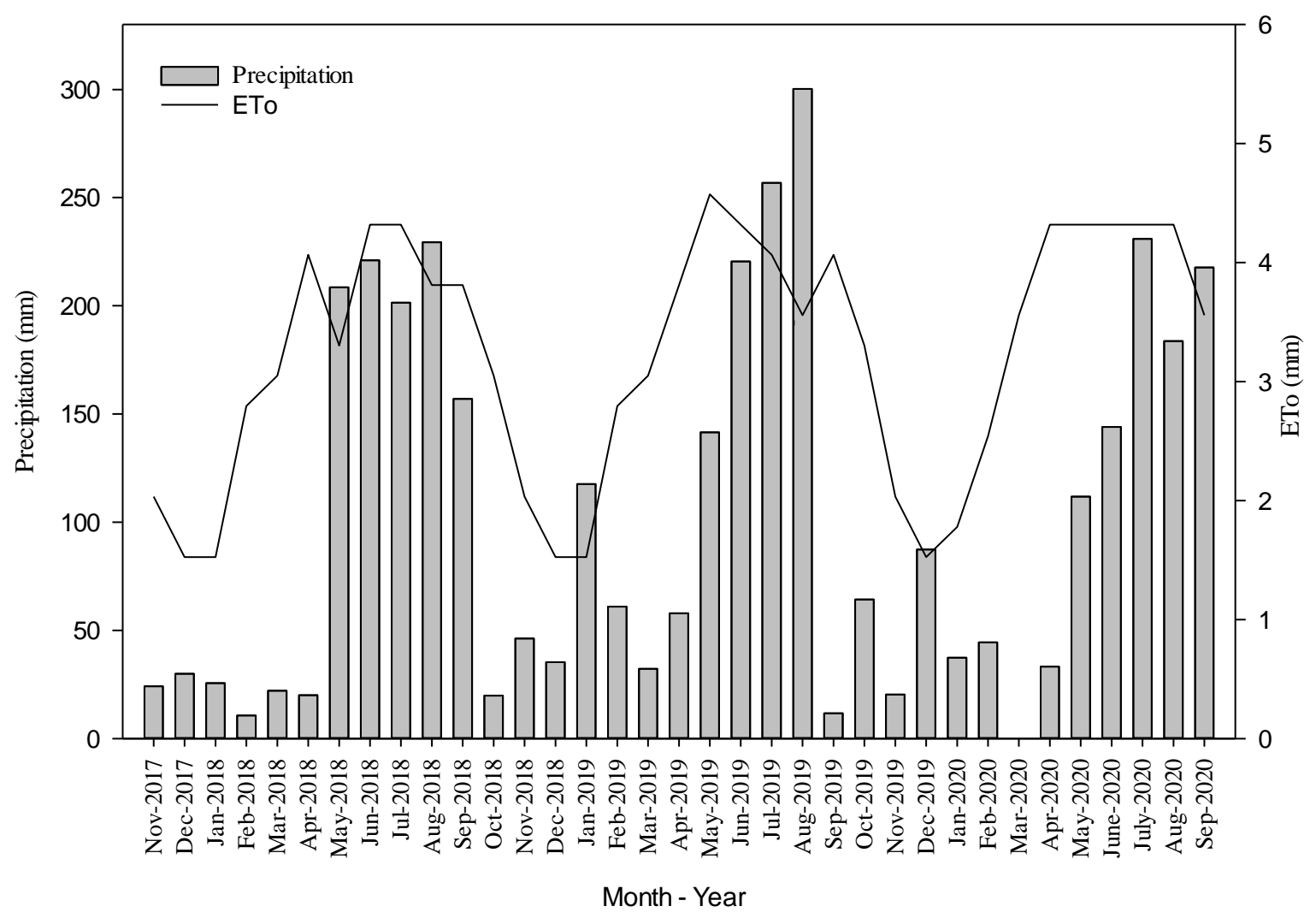

Figure 1. Precipitation at the experimental grove located at the Southwest Florida Research and Education Center (SWFREC) in Immokalee, Florida, from November 2017 through to September 2020.

\subsection{Water Supplied and Water Relations}

\subsubsection{Irrigation Water Quality, Water Supplied, and Crop Coefficient}

The water supplied for irrigation in this study had a very low salt content estimated to be $183 \pm 0.15$ in $\mu \mathrm{S} \mathrm{cm}^{-1}$ and total dissolved solids (TDS) $=121 \pm 0.4 \mathrm{ppm}$. The daily water supplied to citrus trees in various irrigation treatments introduced an increasing trend from January (6.3 $\mathrm{L} \mathrm{tree}^{-1}$ day $^{-1}$ ) to May ( $40.5 \mathrm{~L} \mathrm{tree}^{-1}$ day $^{-1}$ ). Higher water application is related to the higher evapotranspiration rate of citrus trees, triggered by the rising evaporation rate during this time (Figure 2). 

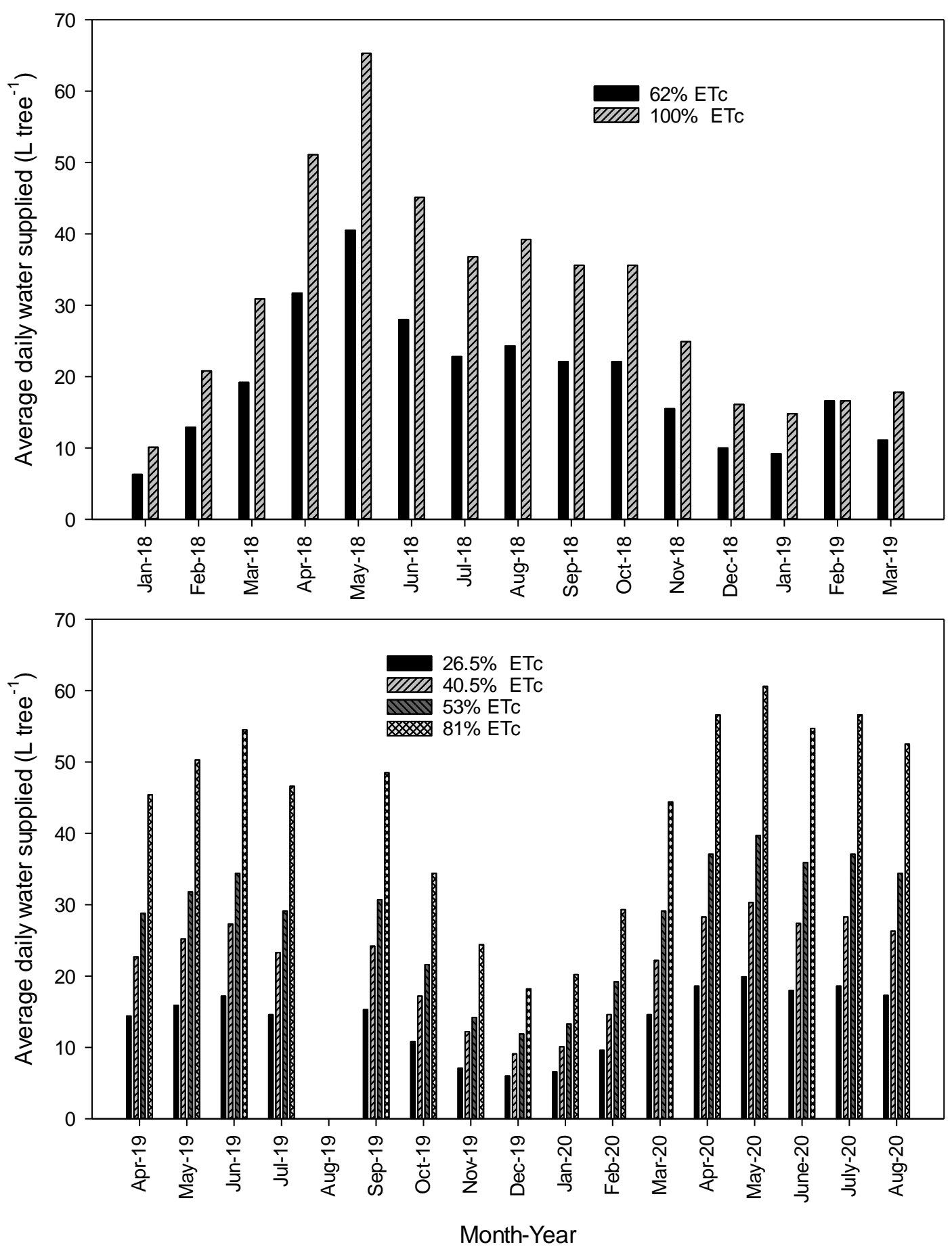

Figure 2. Average daily water supplied to 'Valencia' trees $\left(\mathrm{L}_{\mathrm{tree}} \mathrm{e}^{-1}\right)$ under different irrigation rates from January 2018 through to August 2020 at the experimental grove located at the Southwest Florida Research and Education Center (SWFREC).

However, the lowest rate of daily water supplied to the trees was recorded from January through to February with an average daily rate of 6.3-12.9 and 10.1-20.8 $\mathrm{L}^{\text {tree }}{ }^{-1}$ day $^{-1}$ under lower (62\% ETc) and higher (100\% ETc) irrigation treatments, respectively. The average daily water supplied during 2018 varied from 21.2 to $34.3 \mathrm{~L}^{\text {tree }}{ }^{-1}$ day $^{-1}$ under lower and higher irrigation rates, respectively. As a result of the different planting densities, the volume of water required per hectare increased with increasing the number of trees planted per hectare.

A similar trend was observed during the last 17 months of the treatments, with an average daily water supply of 13.8 to $42.9 \mathrm{~L} \mathrm{tree}^{-1}$ day $^{-1}$ under 26.5 and $81 \%$ ETc, 
respectively. However, the lowest rate of daily water supplied to the trees was recorded during November 2019 through to January 2020 with an average daily rate of 6.6 and $20.9 \mathrm{~L} \mathrm{tree}^{-1}$ day $^{-1}$ under the $26.5 \%$ and $81 \%$ ETc treatments, respectively. Previous studies confirmed a reduction in water supplied of up to $40 \%$ in Verna lemon [40], 30\% in Navel orange [41], 25\% in Nagpur mandarin [35], and 27\% in 'Valencia' sweet orange [6] under different irrigation management conditions without detrimental effects on the trees' growth or yield.

\section{Crop. Coefficient (Kc)}

The highest crop coefficients were 1.1 and 1.0 during May 2018 and 2020, respectively (Table 2). The Kc values were consistent with those found by other scientists [11,42,43]. For example, Alves et al. [42] asserted that the monthly Kc average for citrus trees was in the range of 0.9-1.11. Hla et al. [44] proclaimed a daily Kc for 7-year-old citrus trees between 0.53 and 1.4 in December and mid-July, respectively. In addition, Boman [45] published that the Kc values for young citrus trees doubled from December to June. Such data are closer to the current research results. For example, the Kc values for young citrus trees under 717 trees per acre increased from 0.30 (January 2018), 0.43 (January 2019), or 0.82 (January 2020) to 0.88 (May 2018), 0.91 (June 2019), or 1.01 (May 2020), respectively (Table 2).

Table 2. Average daily crop coefficient (Kc) of 'Valencia' trees at $62 \%$ and $81 \%$ water supply (ETc) irrigation rates among different planting densities for the first year after planting from January 2018 through to March 2019 at the experimental grove located at the Southwest Florida Research and Education Center (SWFREC).

\begin{tabular}{|c|c|c|c|c|c|c|c|}
\hline Month & $\begin{array}{c}\text { Daily ETo } \\
\text {-Penman-Monteith- (mm) }\end{array}$ & $\begin{array}{l}447 \text { Trees } \\
\text { ha }^{-1}\end{array}$ & $\begin{array}{l}512 \text { Trees } \\
\mathrm{ha}^{-1}\end{array}$ & $\begin{array}{l}598 \text { Trees } \\
\text { ha }^{-1}\end{array}$ & $\begin{array}{c}717 \text { Trees } \\
\mathrm{ha}^{-1}\end{array}$ & $\begin{array}{c}745 \text { Trees } \\
\mathrm{ha}^{-1}\end{array}$ & $\begin{array}{l}897 \text { Trees } \\
\text { ha }^{-1}\end{array}$ \\
\hline \multicolumn{8}{|c|}{ Irrigation rate at $62 \% \mathrm{ETc}$} \\
\hline \multicolumn{8}{|c|}{2018} \\
\hline Jan & 1.52 & 0.18 & 0.21 & 0.25 & 0.30 & 0.31 & 0.37 \\
\hline Feb & 2.79 & 0.21 & 0.24 & 0.28 & 0.33 & 0.34 & 0.42 \\
\hline Mar & 3.05 & 0.28 & 0.32 & 0.38 & 0.45 & 0.47 & 0.57 \\
\hline Apr & 4.06 & 0.35 & 0.40 & 0.47 & 0.56 & 0.58 & 0.70 \\
\hline May & 3.30 & 0.55 & 0.63 & 0.73 & 0.88 & 0.92 & 1.10 \\
\hline June & 4.32 & 0.29 & 0.33 & 0.39 & 0.47 & 0.48 & 0.58 \\
\hline July & 4.32 & 0.24 & 0.27 & 0.32 & 0.38 & 0.39 & 0.48 \\
\hline Aug & 3.81 & 0.29 & 0.33 & 0.38 & 0.46 & 0.48 & 0.57 \\
\hline Sep & 3.81 & 0.26 & 0.30 & 0.35 & 0.42 & 0.43 & 0.52 \\
\hline Oct & 3.05 & 0.33 & 0.37 & 0.43 & 0.52 & 0.54 & 0.65 \\
\hline Nov & 2.03 & 0.34 & 0.39 & 0.46 & 0.55 & 0.57 & 0.69 \\
\hline Dec & 1.52 & 0.30 & 0.34 & 0.39 & 0.47 & 0.49 & 0.59 \\
\hline \multicolumn{8}{|c|}{2019} \\
\hline Jan & 1.52 & 0.27 & 0.31 & 0.36 & 0.43 & 0.45 & 0.55 \\
\hline $\mathrm{Feb}$ * & 2.79 & 0.27 & 0.30 & 0.36 & 0.43 & 0.44 & 0.53 \\
\hline Mar & 3.05 & 0.16 & 0.19 & 0.22 & 0.26 & 0.27 & 0.33 \\
\hline Average & 3.00 & 0.29 & 0.33 & 0.38 & 0.46 & 0.48 & 0.58 \\
\hline \multicolumn{8}{|c|}{ Irrigation rate at $81 \%$} \\
\hline \multicolumn{8}{|c|}{2019} \\
\hline Apr & 3.81 & 0.53 & 0.61 & 0.72 & 0.86 & 0.88 & 1.08 \\
\hline May & 4.57 & 0.49 & 0.56 & 0.66 & 0.79 & 0.82 & 1.00 \\
\hline June & 4.32 & 0.57 & 0.65 & 0.76 & 0.91 & 0.94 & 1.14 \\
\hline July & 4.06 & 0.51 & 0.59 & 0.68 & 0.82 & 0.86 & 1.02 \\
\hline Aug ** & 3.56 & - & - & - & - & - & - \\
\hline Sep & 4.06 & 0.53 & 0.61 & 0.72 & 0.86 & 0.88 & 1.06 \\
\hline Oct & 3.30 & 0.47 & 0.53 & 0.62 & 0.75 & 0.78 & 0.94 \\
\hline Nov & 2.03 & 0.54 & 0.62 & 0.72 & 0.86 & 0.9 & 1.08 \\
\hline Dec & 1.52 & 0.53 & 0.61 & 0.72 & 0.85 & 0.9 & 1.08 \\
\hline
\end{tabular}


Table 2. Cont.

\begin{tabular}{|c|c|c|c|c|c|c|c|}
\hline Month & $\begin{array}{c}\text { Daily ETo } \\
\text {-Penman-Monteith- (mm) }\end{array}$ & $\begin{array}{l}447 \text { Trees } \\
\text { ha }^{-1}\end{array}$ & $\begin{array}{l}512 \text { Trees } \\
\text { ha }^{-1}\end{array}$ & $\begin{array}{l}598 \text { Trees } \\
\text { ha }^{-1}\end{array}$ & $\begin{array}{l}717 \text { Trees } \\
\text { ha }^{-1}\end{array}$ & $\begin{array}{l}745 \text { Trees } \\
\text { ha }^{-1}\end{array}$ & $\begin{array}{l}897 \text { Trees } \\
\text { ha }^{-1}\end{array}$ \\
\hline \multicolumn{8}{|c|}{2020} \\
\hline Jan & 1.78 & 0.51 & 0.58 & 0.68 & 0.82 & 0.84 & 1.02 \\
\hline Feb & 2.54 & 0.52 & 0.59 & 0.68 & 0.83 & 0.86 & 1.04 \\
\hline Mar & 3.56 & 0.56 & 0.64 & 0.74 & 0.90 & 0.92 & 1.12 \\
\hline Apr & 4.32 & 0.59 & 0.67 & 0.78 & 0.94 & 0.98 & 1.18 \\
\hline May & 4.32 & 0.63 & 0.72 & 0.84 & 1.01 & 1.04 & 1.26 \\
\hline June & 4.32 & 0.57 & 0.65 & 0.76 & 0.91 & 0.94 & 1.14 \\
\hline July & 4.32 & 0.59 & 0.67 & 0.78 & 0.94 & 0.98 & 1.18 \\
\hline Aug & 4.32 & 0.54 & 0.62 & 0.72 & 0.87 & 0.9 & 1.10 \\
\hline Average & 3.57 & 0.54 & 0.62 & 0.72 & 0.87 & 0.90 & 1.09 \\
\hline
\end{tabular}

${ }^{*}$ Due to field irrigation well maintenance, all the trees were irrigated using the emergency freeze line which represents the same amount of water for all trees. ${ }^{* *}$ Due to heavy precipitation, irrigation was halted.

\subsubsection{Stem water potential ( $\left.\Psi_{\text {stem }}\right)$}

The three-way interaction of irrigation $x$ planting density $x$ month of measurements $(p=0.6208)$ and the two-way interactions of planting density $\mathrm{x}$ irrigation rate $(p=0.9976)$ and irrigation rate $\mathrm{x}$ month of measurements $(p=0.1595)$ did not significantly impact the plant water status during 2018. Additionally, the analysis of variance suggested that there was no significant variation between the irrigation rates alone $(p=0.5654)$ and planting densities alone ( $p=0.0564)$ (Table 3). The results of the $\Psi_{\text {stem }}$ of different irrigation treatments and planting densities of young citrus trees during 2018 reveals that the lower irrigation scheduling $(62 \%$ ETc) did not detrimentally affect the crop water status.

Table 3. Results of model for the stem water potential of young citrus trees under different irrigation rates at different planting densities with stem water potential (MPa) measured over time during 2018 at the experimental grove located at the Southwest Florida Research and Education Center (SWFREC).

\begin{tabular}{cc}
\hline Model Variables and Interaction & Stem Water Potential \\
\cline { 2 - 2 } Irrigation & $\mathbf{P}>\mathbf{F}$ \\
\hline Planting density & 0.5654 \\
Month of measurements & 0.0564 \\
Irrigation $\times$ Planting density & $<0.0001$ \\
Irrigation $\times$ Month of measurements & 0.9976 \\
Irrigation $\times$ Planting density $\times$ Month of & 0.1509 \\
measurements & 0.6208 \\
\hline Main effect means & \\
\hline Irrigation rate & $\mathrm{MPa}$ \\
\hline $62 \%$ & -0.80 \\
$100 \%$ & -0.79 \\
\hline Planting Density (tree per ha) & $\mathrm{MPa}$ \\
\hline 447 & -0.82 \\
512 & -0.85 \\
598 & -0.81 \\
717 & -0.76 \\
745 & -0.76 \\
897 & -0.80 \\
\hline
\end{tabular}

Collected data were separated per month, irrigation treatment, and planting density and then analyzed over time; the results' monthly average is presented in Table 3 . The average $\Psi_{\text {stem }}$ measured under a $62 \%$ ETc irrigation rate was $-0.80 \mathrm{MPa}$ compared with 
$-0.79 \mathrm{MPa}$ under a 100\% ETc irrigation rate. However, both treatment results indicated well-irrigated citrus trees. Planting density did not represent any significant differences among means. The average $\Psi_{\text {stem }}$ ranged between -0.85 and $-0.76 \mathrm{MPa}$ under 512 and 745 trees ha $^{-1}$.

During 2019 and 2020, the irrigation rate significantly impacted the young citrus trees' water status, and none of the treatments represented a detrimental effect on tree water supplied. This was clearly represented by the $\Psi_{\text {stem }}$ ranging from -0.91 to -1.06 under the 81 and $26.5 \%$ ETc, treatments, respectively (Table 4). However, the presented values are similar to the values reported for well-irrigated trees [4-6]. Thus, increasing the irrigation rate to $54.5 \%$ reduced the water stress by $9 \%$.

Table 4. Results of model for the stem water potential of young citrus trees at different irrigation rates under different planting densities with the stem water potential measured over time between 2019 and 2020 at the experimental grove located at the Southwest Florida Research and Education Center (SWFREC).

\begin{tabular}{cc}
\hline Model Variables and Interaction & Stem Water Potential (MPa) \\
\cline { 2 - 2 } Irrigation & $\mathbf{P}>\mathbf{F}$ \\
Planting density & 0.0086 \\
Month of measurements & 0.6051 \\
Irrigation $\times$ Planting density & $<0.0001$ \\
Irrigation $\times$ Month of measurements & 0.4622 \\
Irrigation $\times$ Planting density $\times$ Month of & 0.4414 \\
measurements & 0.5733 \\
\hline Main effect means & \\
\hline Irrigation rate (\%) & MPa \\
\hline 26.5 & -1.06 \\
40.5 & -1.05 \\
53 & -0.99 \\
81 & -0.91 \\
\hline Planting Density (tree per ha) & MPa \\
\hline 447 & -0.99 \\
512 & -0.95 \\
598 & -0.97 \\
717 & -1.00 \\
745 & -1.02 \\
897 & -0.95 \\
\hline
\end{tabular}

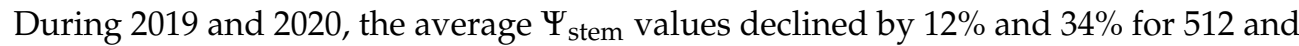
745 trees per ha, respectively, compared with 2018. In 2018, the average $\Psi_{\text {stem }}$ values ranged from -0.85 to $-0.76 \mathrm{MPa}$ for 512 and 745 trees per ha. However, all the $\Psi_{\text {stem }}$ values were similar to observations reported for non-stressed citrus trees with values around $1 \mathrm{MPa}$ by Gasque et al. [1] [10]. Shackel et al. [46] showed that the $\Psi_{\text {stem }}$ for trees reacts uniquely under various irrigation management situations. They presumed that the $\Psi_{\text {stem }}$ of trees diversified based on the volume of water provided. For instance, the $\Psi_{\text {stem }}$ declined from -0.8 to $-1.5 \mathrm{MPa}$ when the water mass lessened from 900 to $50 \mathrm{~mm}$ [47].

\subsubsection{Soil Water Contents}

Traditional methods for monitoring crop water stress include measurements of soil water contents. However, farmers in south Florida have irrigated using experience and evaluation based on visual inspections of the plant and feeling soil moisture status using the hand method and estimating irrigation requirements [48]. This management has produced a susceptibility to over-irrigation. In contrast, irrigation scheduling, according to soil moisture and plant water condition sensors, can improve the crop water productivity 
and enhance water conservation practices. Furthermore, the use of sensors is critical for scheduling irrigation and maximizing water supplied efficiency in irrigated plants.

Although soil moisture content data were collected every $30 \mathrm{~min}$, the average daily values were considered for statistical analysis. As anticipated, the soil moisture contents under different irrigation treatments corresponded to the supplied water volume. Thus, high soil moisture values were recognized at higher irrigation rates. For instance, during $2018,100 \%$ ETc treatment represented an average soil water content in the soil profile of $16 \%$, with higher moisture contents concentrated in the lower soil depth $(30-45 \mathrm{~cm})$. That soil depth contained $28 \%$ more water than the soil surface $(0-15 \mathrm{~cm})$ (Table 5).

Table 5. Results of the model for daily soil moisture contents under different irrigation rates at different planting densities during April 2018 and February 2019 measurements at the experimental grove located at the Southwest Florida Research and Education Center (SWFREC).

\begin{tabular}{|c|c|c|}
\hline \multirow{3}{*}{ Model Variables and Interaction } & \multicolumn{2}{|c|}{ Soil Moisture Contents } \\
\hline & 2018 & 2019 \\
\hline & \multicolumn{2}{|c|}{$\mathbf{P}>\mathbf{F}$} \\
\hline Irrigation & $<0.0001$ & $<0.0001$ \\
\hline Planting density & $<0.0001$ & $<0.0001$ \\
\hline Depth of measurements & $<0.0001$ & $<0.0001$ \\
\hline Irrigation $\times$ planting density & $<0.0001$ & $<0.0001$ \\
\hline Irrigation $\times$ depth of measurements & $<0.0001$ & $<0.0001$ \\
\hline Irrigation $\times$ Planting density $\times$ Month of measurements & $<0.0001$ & $<0.0001$ \\
\hline Main effect means & \multicolumn{2}{|c|}{$(\%)$} \\
\hline \multicolumn{3}{|l|}{ Irrigation rate $(\% \mathrm{ETc})$} \\
\hline $62 \%$ & 15 & 9 \\
\hline $100 \%$ & 16 & 10 \\
\hline \multicolumn{3}{|l|}{ Depth of measurements $(\mathrm{cm})$} \\
\hline $0-15$ & 13 & 9 \\
\hline $15-30$ & 16 & 11 \\
\hline $30-45$ & 18 & 10 \\
\hline \multicolumn{3}{|l|}{ Planting Density (tree per ha) } \\
\hline 447 & 15 & 9 \\
\hline 512 & 15 & 8 \\
\hline 598 & 14 & 10 \\
\hline 717 & 15 & 10 \\
\hline 745 & 18 & 13 \\
\hline 897 & 12 & 8 \\
\hline
\end{tabular}

During 2018-2019, the three-way interaction of irrigation $x$ planting density $x$ month of measurements $(p<0.0001)$ and the two-way interactions of planting density $\times$ irrigation rate $(p<0.0001)$ and irrigation rate $\mathrm{x}$ soil depth $(p<0.0001)$ significantly affected the soil water content (SWC) (Table 5). However, the variation in mean SWC in the soil profile during the growing season under different irrigation treatments indicated that the $62 \%$ irrigation rate successfully sustained the SWC near the field capacity $(10 \%)$ in the top-soil surface. In support of this finding, Shahnazari et al. [46] and [49] indicated that the lower irrigation volume maintained the plant water status closer to the optimal levels.

Although the higher irrigation rate $(100 \%)$ represented higher soil water contents during the first 15 months of the study, the lower irrigation rate (62\%) did not represent biological stress as a result of one emitter per tree, regardless of the planting density (Figure 3), supported by the appropriate stem water potential. The yearly average SWC indicated a significant increase in the SWC over time under some planting densities with higher irrigation rates, which could result in the depletion and losses of added and soil-stored 
nutrients through leaching within the soil profile. As a result, the irrigation rate was modified for the remainder of the experiment to represent $26.5 \%, 40.5 \%, 53 \%$, and $81 \%$ ETc.

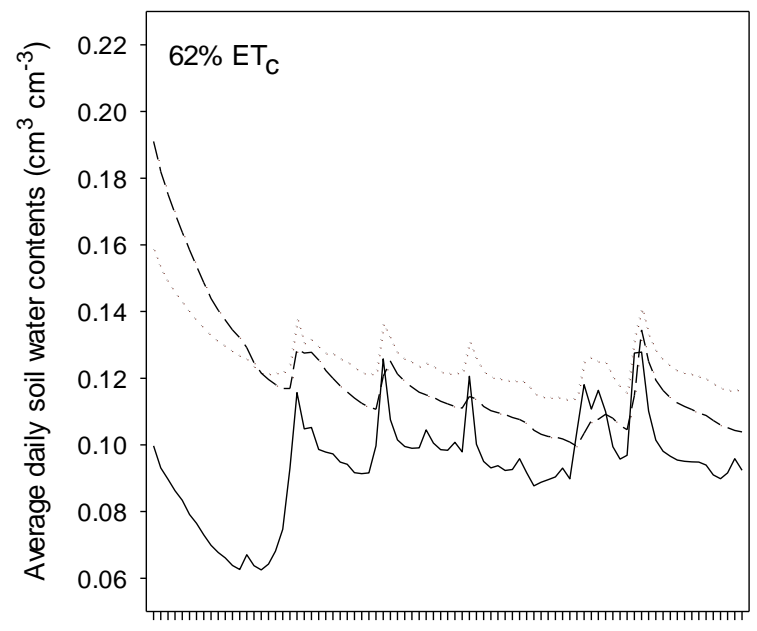

Daily (October 2018 - January 2019)

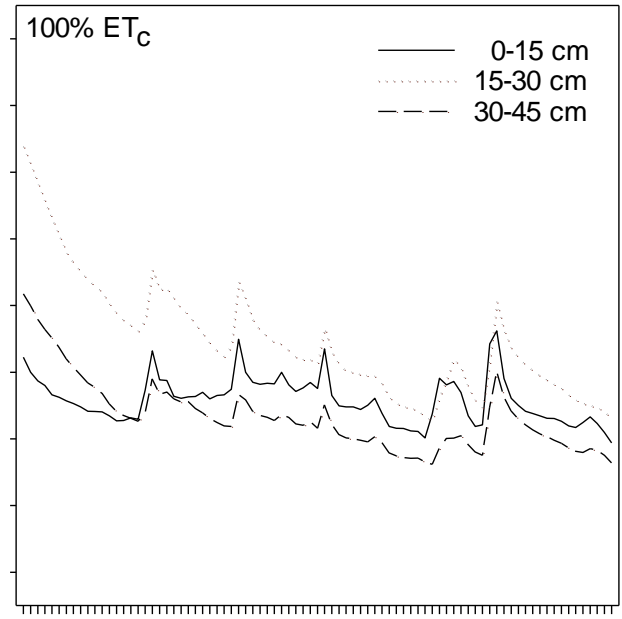

Daily (October 2018 - January 2019)

Figure 3. Average daily soil moisture changes under different irrigation rates at different soil depths between 2018 and 2019 at Southwest Florida Research and Education Center (SWFREC) experimental grove.

When the irrigation rates were adjusted, the soil moisture contents under different irrigation treatments corresponded to the supplied water volume represented a different trend with a higher moisture content in the topsoil surface. Increasing the irrigation rate from $26.5 \%$ to $81 \%$ ETc increased the soil moisture content with an estimated value of $40 \%$ from 0.074 to 0.124 , respectively (Table 6 ). In addition, using one emitter to irrigate two trees under a higher planting density lowered the soil moisture contents compared to the 2018 results when one emitter was used to irrigate one tree.

Table 6. Results of a model for daily soil moisture contents under different irrigation rates at different planting densities between April 2019 and August 2020 measurements at the demonstration grove at the Southwest Florida Research and Education Center (SWFREC).

\begin{tabular}{ccc}
\hline & \multicolumn{2}{c}{ Soil Moisture Contents } \\
\cline { 2 - 3 } Model Variables and Interaction & $\mathbf{2 0 1 9}$ & $\mathbf{2 0 2 0}$ \\
\cline { 2 - 3 } & \multicolumn{2}{c}{$\mathbf{P}>\mathbf{F}$} \\
\hline Irrigation & $<0.0001$ & $<0.0001$ \\
Planting density & $<0.0001$ & $<0.0001$ \\
Depth of measurements & $<0.0001$ & $<0.0001$ \\
Irrigation $\times$ Planting density & $<0.0001$ & $<0.0001$ \\
Irrigation $\times$ depth of measurements & $<0.0001$ & $<0.0001$ \\
Irrigation $\times$ Planting density $\times$ Month of measurements & $<0.0001$ & $<0.0001$ \\
\hline Main effect means & & $(\%)$ \\
\hline Irrigation rate (\% ETc) & & \\
\hline 26.5 & 0.074 & 0.071 \\
40.5 & 0.081 & 0.084 \\
53 & 0.091 & 0.115 \\
\hline 81 & 0.124 & \\
\hline Depth of measurements $(\mathrm{cm})$ & & 0.091 \\
\hline $0-15$ & 0.104 & 0.102 \\
$15-30$ & 0.108 & 0.095 \\
\hline $30-45$ & 0.101 & \\
\hline
\end{tabular}


Table 6. Cont.

\begin{tabular}{ccc}
\hline & \multicolumn{2}{c}{ Soil Moisture Contents } \\
\cline { 2 - 3 } Model Variables and Interaction & $\mathbf{2 0 1 9}$ & $\mathbf{2 0 2 0}$ \\
\cline { 2 - 3 } & \multicolumn{2}{c}{$\mathbf{P}>\mathbf{F}$} \\
\hline Planting Density (tree per ha) & 0.110 & 0.103 \\
447 & 0.098 & 0.094 \\
512 & 0.106 & 0.083 \\
598 & 0.112 & 0.098 \\
717 & 0.124 & 0.110 \\
745 & 0.089 & 0.075 \\
897 & &
\end{tabular}

During 2019-2020, the three-way interaction of irrigation $x$ planting density $x$ month of measurements $(p<0.0001)$ and the two-way interactions of planting density $\mathrm{x}$ irrigation rate $(p<0.0001)$ and irrigation rate $x$ soil depth $(p<0.0001)$ significantly affected the soil water content (SWC) (Table 6). However, the variation in the mean SWC in the soil profile during the growing season under different irrigation treatments indicated that the $81 \%$ irrigation rate successfully maintained the SWC near the field capacity in the top-soil surface (Figure 4).
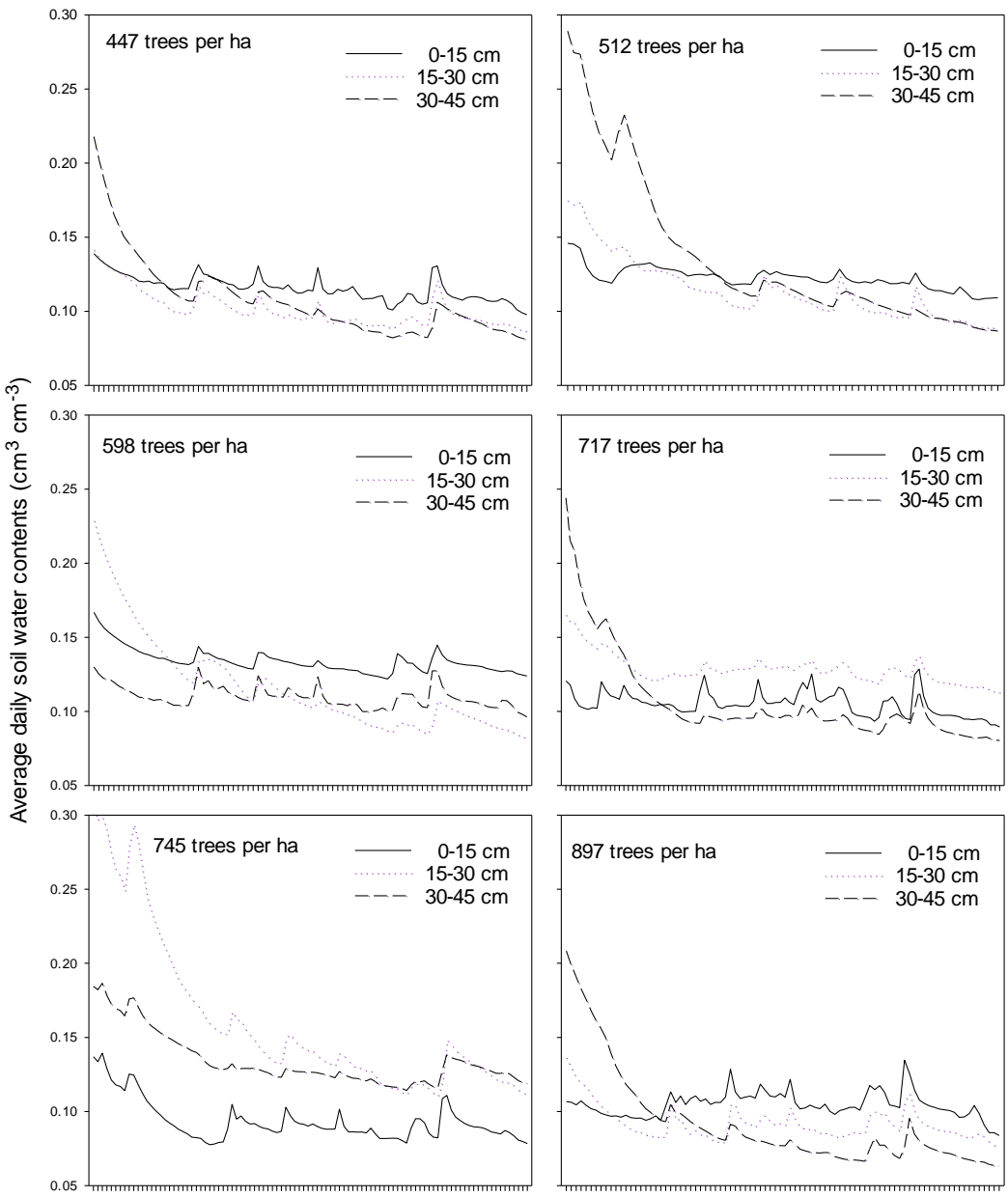

Daily (October 2018 - January 2019)

Daily (October 2018 - January 2019)

Figure 4. Average daily soil moisture changes under different planting densities at different soil depths between 2018 and 2019 at the Southwest Florida Research and Education Center (SWFREC) experimental grove. 
Although lower irrigation rates ( $40.5 \%$ and $53 \%$ ) represented lower soil water contents compared with $81 \%$ ETc, they were close to the safe margin of $20 \%$ field capacity depletion during the study; the lower irrigation rate of $26.5 \%$ ETc represented the lowest SWC in the top soil surfaces, regardless of planting density (Figure 5).

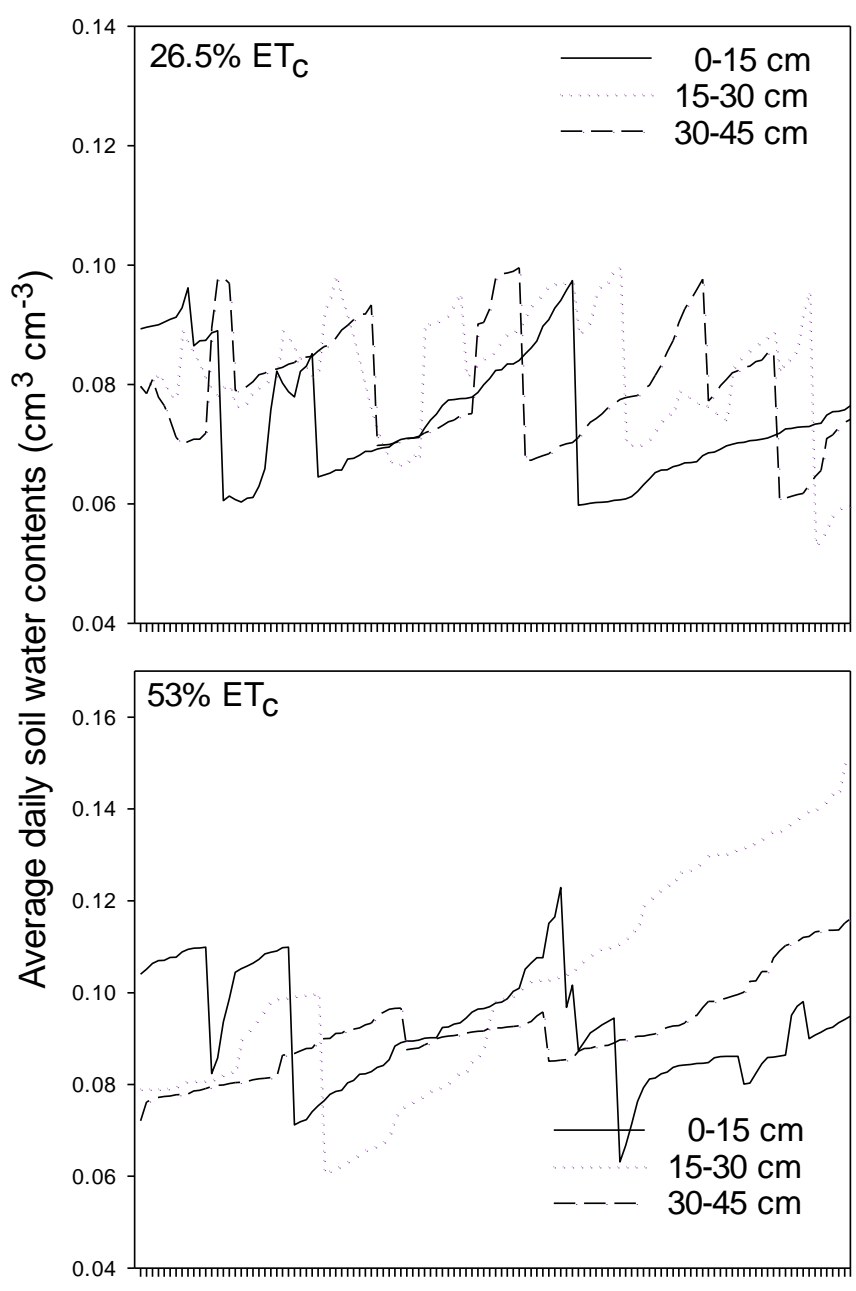

Daily (September 2019 - February 2020)
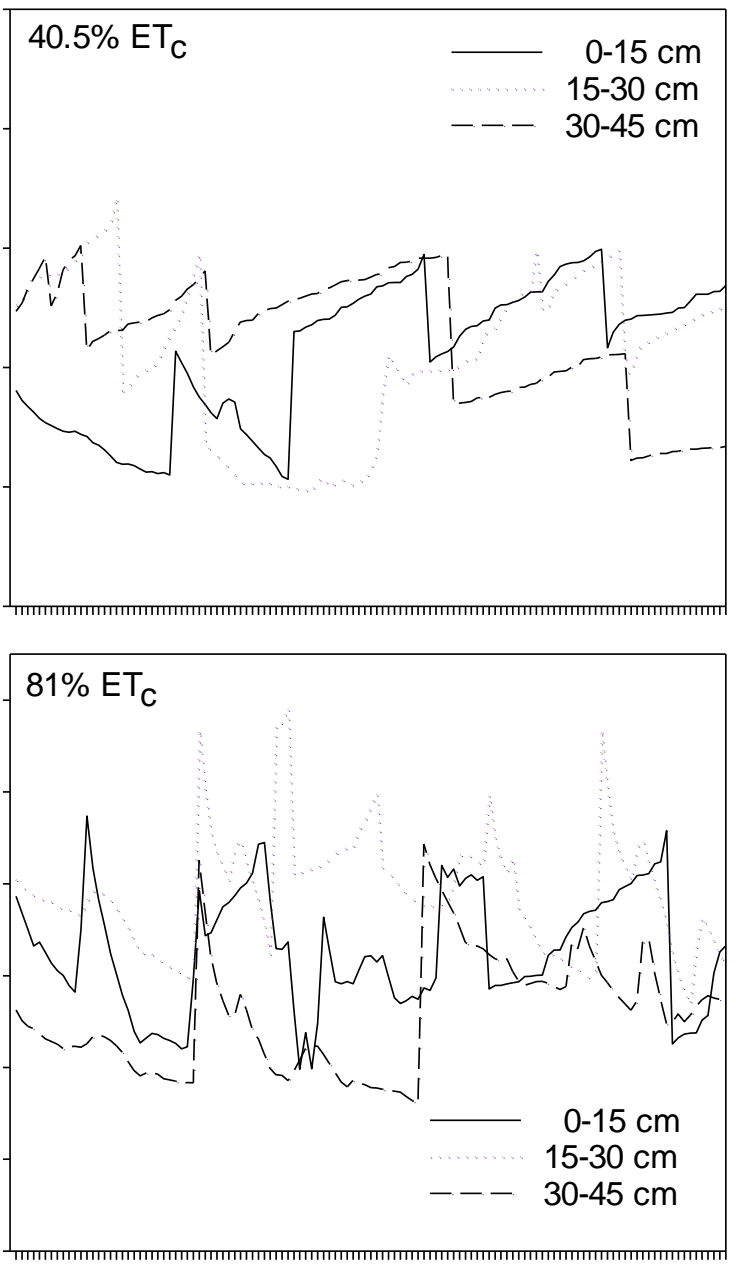

Daily (September 2019 - February 2020)

Figure 5. Average daily soil moisture changes under different irrigation rates at different soil depths between 2019 and 2020 at the Southwest Florida Research and Education Center (SWFREC) experimental grove.

Increasing the planting density significantly impacted the soil moisture contents regardless of one or two trees being irrigated with one emitter. Increasing the planting density to 897 trees per ha and using one emitter to irrigate two trees resulted in sufficient soil moisture contents at 0.089 , which is close to the field capacity of Florida sandy soils (0.10) (Figure 6). However, while other parameters were considered in the first publication of this series, the $26.5 \%$ ETc treatment is not recommended. 


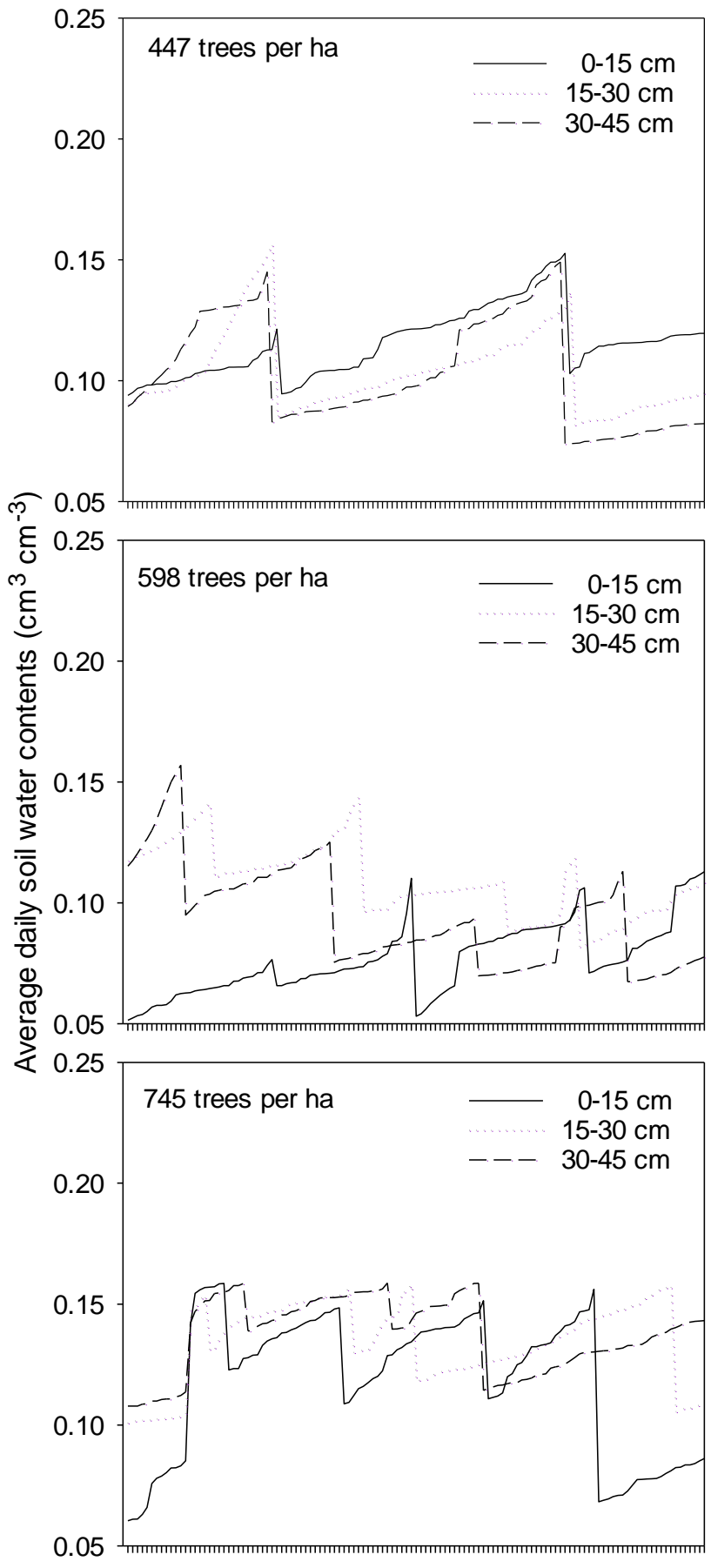

Daily (September 2019 - February 2020)
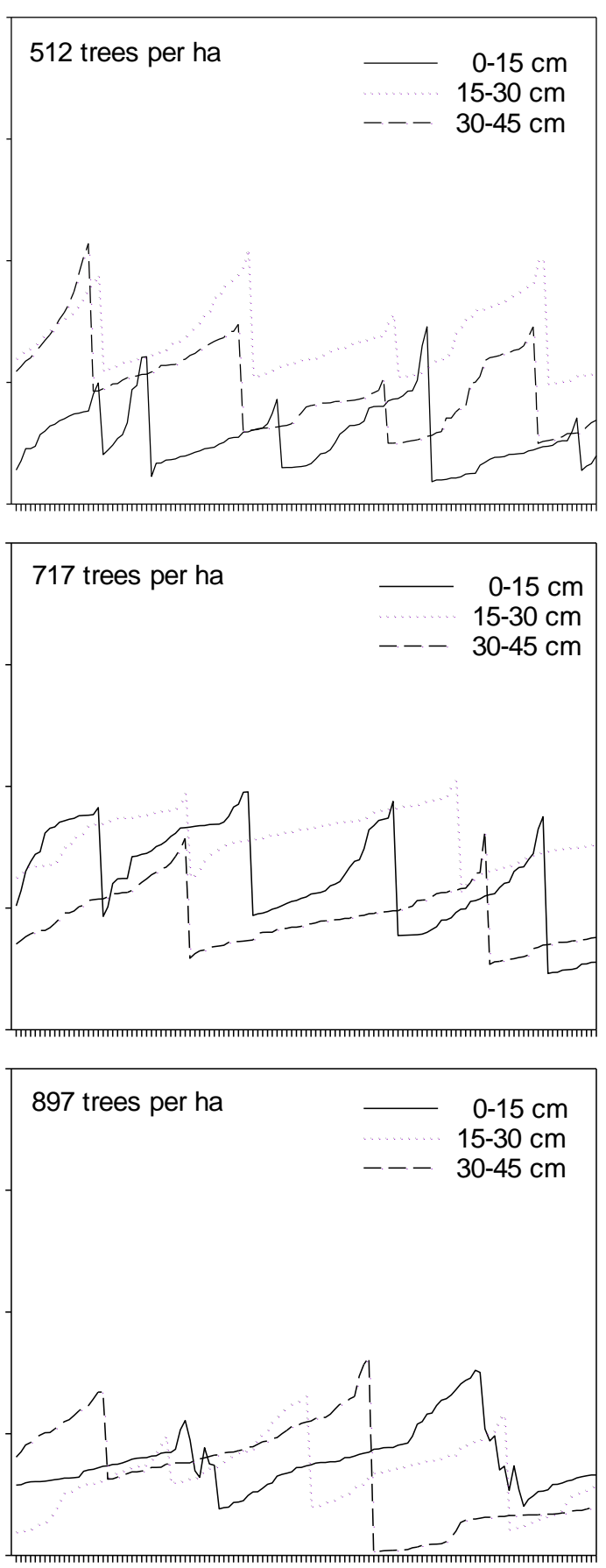

Daily (September 2019 - February 2020)

Figure 6. Average daily soil moisture changes under different planting densities at different soil depths between 2019 and 2020 at the Southwest Florida Research and Education Center (SWFREC) experimental grove.

\subsubsection{Soil Salinity (EC)}

Soil salinity is one of the most significant abiotic limitations affecting crop growth and development in irrigation management [50]. The unfavorable effects of salinity on crop development are linked with the rise of nutrients to a toxic level leading to nutritional variations [51,52] and declining plant growth [53]. The citrus tree 'Valencia' is recognized as a salt-sensitive crop [54] and is negatively influenced by a soil conductivity of about 2.5-3 dS m ${ }^{-1}$ [55]. 
In the current study, the electrical conductivity of the soil solution was higher in lower irrigation treatments than the higher irrigation treatment throughout the experiment (Table 7). This could be the result of the lower leaching of fertilizers during the growing period when plants were fully irrigated.

Table 7. Results of soil salinity (EC) under different irrigation rates at different planting densities at different soil depths during October 2018 and May 2020 at the experimental grove at Southwest Florida Research and Education Center (SWFREC).

\begin{tabular}{ccc}
\hline Measured Variables & EC-2018 & EC-2020 \\
\hline Irrigation & 0.1561 & 0.1513 \\
Planting density & 0.1496 & 0.7743 \\
Depth of measurements & 0.1095 & $<0.0001$ \\
Irrigation x Planting density & 0.2101 & 0.7850 \\
Irrigation x depth of measurements & 0.9401 & 0.4846 \\
Irrigation x Planting density x Month of measurements & 0.4367 & 0.9827 \\
\hline Main effect & & \\
\hline Irrigation rate & $\mu \mathrm{Scm} \mathrm{cm}^{-1}$ & $\mu \mathrm{S} \mathrm{cm}$ \\
\hline $26.5 \%$ & - & 62.23 \\
40.5 & - & 43.42 \\
$53 \%$ & - & 46.08 \\
$81 \%$ & - & 41.87 \\
\hline Depth of measurements (cm) & & \\
\hline $0-15$ & 51.4 & 37.31 \\
$15-30$ & 46.6 & 36.58 \\
\hline $30-45$ & 40.5 & \\
\hline Planting Density (trees per acre) & & 47.69 \\
447 & 50.1 & 36.74 \\
512 & 37.7 & 48.86 \\
598 & 44.4 & 45.25 \\
\hline 717 & 43.3 & 63.3 \\
\hline
\end{tabular}

* During 2018 soil salinity was determined under two irrigation rates and were 49.2 and $43.2 \mu \mathrm{S} \mathrm{cm}{ }^{-1}$ under $62 \%$ and $100 \%$ ETc, respectively.

Thus, soil conductivity is negatively correlated with the volume of irrigation. Neither the three-way interaction of irrigation rate $\mathrm{x}$ planting density $\mathrm{x}$ soil depth $(p=0.4367)$ nor the two-way interaction of irrigation rate $x$ planting density $(p=0.2102)$ significantly influenced the soil electrical conductivity (EC). Besides this, irrigation rate alone $(p=0.1561)$, planting density alone $(p=0.1497)$, and soil depth alone $(p=0.1095)$ did not significantly influence the soil EC; however, the soil EC decreased with increasing soil depths.

During May 2020, soil depth alone significantly $(p<0.0001)$ affected salt accumulation when decreasing the salt accumulation with increasing the soil depth by $\approx 59 \%$ from $62.3 \mu \mathrm{S} \mathrm{cm}^{-1}$ in the soil surface $(0-15 \mathrm{~cm})$ to $36.6 \mu \mathrm{S} \mathrm{cm}^{-1}$ in the greater soil depth $(30-45 \mathrm{~cm})$. The EC of the soil solution was higher in the lower irrigation treatments (26.5\%ETc) and decreased with increasing the irrigation rate from $62.2 \mu \mathrm{S} \mathrm{cm}-1$ under the irrigation rate of $26.5 \%$ ETc to $41.8 \mu \mathrm{S} \mathrm{cm}^{-1}$ under the irrigation rate of $81 \%$ ETo (Table 7 ). This could be the result of leaching and dilution during the irrigated period.

\section{Conclusions}

The objective of this project was to determine the amount of irrigation required to grow young citrus trees at different planting densities without a detrimental effect on the water relation parameters. The $62 \%$ ETc irrigation treatment exerted promising results during the first 15 months. The $62 \%$ irrigation rate did not significantly introduce abiotic stress on 
young citrus trees during the first year. Although increasing the planting density from 717 to 897 trees per ha reduced the water application on average by $37 \%$, the $81 \%$ irrigation rate effectively maintains water relation parameters, including soil moisture content, salinity, and stem water potential, in the optimum range. Thus, the application of an $81 \%$ ETc irrigation rate in citrus is more efficient than the conventional $100 \%$ ETc treatments under the southwest Florida environments and supported the finding of $[19,22,23]$ for appropriate water requirements for young citrus trees at around $80 \%$ of the daily ETo. Hence, the useful and reliable data revealed in this work could be used to improve water management under commercial applications during the first three years of young citrus tree growth under grove conditions.

Author Contributions: S.A.H., Conceptualization, Data curation, Investigation, Methodology, Visualization, Formal analysis, Writing original draft, and Writing—review and editing; K.T.M., Conceptualization, Funding acquisition, project administration, Resources, Supervision, Visualization, and Writing-review and editing. All authors have read and agreed to the published version of the manuscript.

Funding: This research was funded by Southwest Florida Water Management District (grant no P0093882).

Institutional Review Board Statement: Not applicable.

Informed Consent Statement: Not applicable.

Data Availability Statement: Not applicable.

Conflicts of Interest: The authors declare no conflict of interest.

\section{References}

1. Gasque, M.; Marti, P.; Beatriz Granero, B.; González-Altozano, P. Effects of long-term summer deficit irrigation on 'Navelina' citrus trees. Agric. Water Manag. 2016, 169, 140-147. [CrossRef]

2. Behboudian, M.H.; Mills, T.M. Deficit irrigation in deciduous orchards. Hortric. Rev. 1997, 21, $105-131$.

3. Li, S.H.; Huguet, J.G.; Schoch, P.G.; Orlando, P. Responses of peach tree growth and cropping to soil water deficit at various phenological stages of fruit development. J. Hortric. Sci. 1989, 64, 541-552. [CrossRef]

4. Berman, M.E.; DeJong, T.M. Water stress and crop load effects on fruit fresh and dry weights in peach (Prunus persica). Tree Physiol. 1996, 16, 859-864. [CrossRef] [PubMed]

5. Naor, A.; Klein, I.; Hupert, H.; Greenblat, Y.; Peres, M.; Kaufman, A. Water stress and crop level interactions in relation to nectarine yield, fruit size distribution and water potentials. J. Am. Soc. Hortric. Sci. 1999, 124, 189-193. [CrossRef]

6. Boland, A.; Mitchell, P.D.; Jerie, P.H.; Godwin, I. The effect of regulated deficit irrigation on tree water use and growth of peach. J. Hortric. Sci. 1993, 68, 261-274. [CrossRef]

7. Steduto, P.; Hsiao, T.C.; Fereres, E.; Raes, D. (Eds.) Crop Yield Response to Water, FAO Irrigation and Drainage Paper; Food and Agriculture Organization of the United Nations: Rome, Italy, 2012; Available online: http://www.fao.org/3/i2800e/i2800e.pdf (accessed on 4 December 2020).

8. García-Tejero, I.; Romero-Vicente, R.; Jiménez-Bocanegra, J.A.; Martínez García, G.; Durán-Zuazo, V.H.; Muriel-Fernández, J.L. Response of citrus trees to deficit irrigation during different phenological periods in relation to yield, fruit quality and water productivity. Agric. Water Manag. 2010, 97, 689-699. [CrossRef]

9. Hamido, S.; Ebel, R.C.; Morgan, K. Interaction of huanglongbing and foliar applications of copper on water relations of Citrus sinensis cv. Valencia. Plants 2019, 8, 298. [CrossRef] [PubMed]

10. Hamido, S.A.; Morgan, K.T.; Ebel, R.C.; Kadyampakeni, D.M. Improved irrigation management of sweet orange with Huanglongbing. HortScience 2017, 52, 916-921. [CrossRef]

11. Hamido, S.A.; Morgan, K.T.; Kadyampakeni, D.M. The effect of Huanglongbing on young citrus tree water use. HortTechnology 2017, 27, 659-665. [CrossRef]

12. Hamido, S.A.; Morgan, K.T. Harvesting method affects water dynamics and yield of sweet orange with Huanglongbing. Agriculture 2018, 8, 38. [CrossRef]

13. Atta, A.A.; Morgan, K.T.; Hamido, S.A.; Kadyampakeni, D.M.; Mahmoud, K.A. Water and soil nutrient dynamics of Huanglongbing-affected citrus trees as impacted by ground-applied nutrients. Agronomy 2020, 10, 1485. [CrossRef]

14. Abrisqueta, I.; Conejero, W.; Valdés-Vela, M.; Vera, J.; Ortuño, M.F.; Ruiz-Sánchez, M.C. Stem water potential estimation of drip-irrigated early-maturing peach trees under Mediterranean conditions. Comput. Electron. Agric. 2015, 114, 7-13. [CrossRef]

15. Naor, A.; Hubert, H.; Greenblat, V.; Peres, M.; Klein, I. The response of nectarine fruit size and midday stem water potential to irrigation level in stage III and crop load. J. Am. Soc. Hortic. Sci. 2001, 126, 140-143. [CrossRef] 
16. Obreza, T.A.; Pitts, D.J.; Parsons, L.R.; Wheaton, T.A.; Morgan, K.T. Soil water-holding characteristics affects citrus irrigation scheduling strategy. Proc. Fla. State Hortric. Soc. 1997, 110, 36-39.

17. Abrisqueta, I.; Vera, J.; Tapia, L.M.; Abrisqueta, J.M.; Ruiz-Sánchez, M.C. Soil water content criteria for peach trees water stress detection during the postharvest period. Agric. Water Manag. 2012, 104, 62-67. [CrossRef]

18. Ferreira, M.I. Stress Coefficients for Soil Water Balance Combined with Water Stress Indicators for Irrigation Scheduling of Woody Crops. Horticulturae 2017, 3, 38. [CrossRef]

19. Jones, H.G. Monitoring plant and soil water status: Established and novel methods revisited and their relevance to studies of drought tolerance. J. Exp. Bot. 2007, 58, 119-130. [CrossRef]

20. Morgan, K.T. Determination of evapotranspiration rates in citrus groves with electronic soil moisture probes. Proc. Fla. State Hortric. Soc. 1992, 105, 63-66.

21. Morgan, K.T.; Obreza, T.A.; Kadyampakeni, D.; Hamido, S.; Ferrarezi, R.; Zekri, Z. Nutrition of Florida Citrus Trees, 3rd ed.; Chapter 9. Irrigation Management to Improve Nutrient Uptake, EDIS; 2020; Volume 2020, Available online: https:/ /journals.flvc.org/ edis/article/view/119811 (accessed on 4 December 2020).

22. Mounzer, O.H.; Mendoza, H.R.; Abrisqueta, I.; Vera, J.; Ruiz-Sanchez, M.C.; Tapia, L.M.; Plana, V.; Abrisqueta, J.M. Estimating evapotranspiration by capacitance and neutron probes in a drip-irrigated apricot orchard. Interciencia 2008, 33, 586-590.

23. Chappell, M.; Dove, S.K.; van Iersel, M.W.; Thomas, P.A.; Ruter, J. Implementation of wireless sensor networks for irrigation control in three container nurseries. HortTechnology 2013, 23, 747-753. [CrossRef]

24. Lichtenberg, E.; Majsztrik, J.; Saavoss, M. Profitability of sensor-based irrigation in greenhouse and nursery crops. HortTechnology 2013, 23, 770-774. [CrossRef]

25. Morgan, K.T.; Obreza, T.A.; Scholberg, J.M.S.; Parsons, L.R.; Wheaton, T.A. Citrus water uptake dynamics on a sandy Florida Entisol. Soil Sci. Soc. Am. J. 2006, 70, 90-97. [CrossRef]

26. Morgan, K.T.; Zotarelli, L.; Dukes, M.D. Use of irrigation technologies for citrus trees in Florida. Horttechnology 2010, 20 , 74-81. [CrossRef]

27. Kim, J.; Lea-Cox, J.; Chappell, M.; van Iersel, M.W. Wireless sensors networks for optimization of irrigation, production, and profit in ornamental production. Acta Hortic. 2014, 1037, 643-650.

28. Fares, A.; Alva, A.K. Estimation of citrus evapotranspiration by soil water mass balance. Soil Sci. 1999, 164, 302-310. [CrossRef]

29. Rogers, J.S.; Bartholic, J.F. Estimated evapotranspiration and irrigation requirements for citrus. Proc. Soil Crop Sci. Soc. Fla. 1976, $35,111-117$.

30. Romero, C.C.; Dukes, M.D.; Baigorria, G.A.; Cohen, R. Comparing theoretical irrigation requirement and actual irrigation for citrus in Florida. Agric. Water Manag. 2009, 96, 473-483. [CrossRef]

31. De Medeiros, G.A.; Arruda, F.B.; Sakai, E. Crop coefficient for irrigated beans derived using three reference evaporation methods. Agric. For. Meteorol. 2005, 135, 135-143. [CrossRef]

32. Allen, R.G.; Pereira, L.S.; Raes, D.; Smith, M. Crop Evapotranspiration: Guidelines for Computing Crop Water Requirements Food and Agriculture Organization of the United Nations, Rome. 1998. Available online: http://www.fao.org/3/X0490E/X049 0E00.htm (accessed on 4 December 2020).

33. Rogers, J.; Allen, L.; Calvert, D. Evapotranspiration from a humid-region developing citrus grove with grass cover. Trans. Asae. 1983, 26, 1778-1783. [CrossRef]

34. Peddinti, S.R.; Kambhammettu, B.P. Dynamics of crop coefficients for citrus orchards of central India using water balance and eddy covariance flux partition techniques. Agric. Water Manag. 2019, 212, 68-77. [CrossRef]

35. Alves, J.; Folegatti, M.V., Jr.; Parsons, L.R.; Bandaranayake, W.; da Silva, C.R.; da Silva, T.J.A.; Campeche, L.F.S.M. Determination of the crop coefficient for grafted 'Tahiti' lime trees and soil evaporation coefficient of rhodic kandiudalf clay soil in Sao Paulo, Brazil. Irrig. Sci. 2007, 25, 419-428. [CrossRef]

36. Obreza, T.A.; Schumann, A. Keeping water and nutrients in the Florida citrus tree. Horttechnology 2010, 20, 67-73. [CrossRef]

37. Hamido, S.A.; Morgan, K.T. Effect of Various Irrigation Rates on Growth and Root Development of Young Citrus Trees in High-Density Planting. Plants 2020, 9, 1462. [CrossRef] [PubMed]

38. Barker, J.B.; Heeren, D.M.; Neale, C.M.U.; Rudnick, D.R. Evaluation of variable rate irrigation using a remote-sensing-based model. Agric. Water Manag. 2018, 203, 63-74. [CrossRef]

39. Hanlon, E.A.; Gonzalez, J.S.; Bartos, J.M. Institute of Food and Agricultural Sciences (IFAS) Extension Soil Testing Laboratory (ESTL) and Analytical Research Laboratory (ARL) Chemical Procedures and Training Manual; University of Florida: Gainesville, FL, USA, 1997.

40. Sáchez Blanco, M.J.; Torrecillas, A.; León, A.; Amor, F.D. Growth of 'Verna' lemons under different irrigation regimes. Adv. Hortic. Sci. 1989, 3, 109-111.

41. Holzapfel, E.A.; Lopez, C.; Joublan, J.P.; Matta, R. The effect of water and fertigation on canopy growth and yield on 'thompson Navel' Oranges. Chil. J. Agric. Res. 2001, 61, 51-60.

42. Panigrahi, P.; Srivastava, A.K. Water and nutrient management effects on water use and yield of drip irrigated citrus in vertisol under a sub-humid region. J. Integr. Agric. 2017, 16, 1184-1194. [CrossRef]

43. Yang, S.L.; Aydin, M.; Yano, T.; Li, X. Evapotranspiration of orange trees in greenhouse lysimeters. Irrig. Sci. 2003, 21, 145-149. [CrossRef]

44. Hla, A.K.; Martin, E.C.; Waller, P.M.; Slack, D.C. Heat unit-based crop coefficient for grapefruit trees. J. Appl. Eng. Agric. 1997, 13, 485-489. 
45. Boman, B.J. Evapotranspiration by young Florida flatwoods citrus trees. J. Irrig. Drainage Eng. 1994, 120, 81-88. [CrossRef]

46. Shahnazari, A.; Liu, F.; Andersen, M.N.; Jacobsen, S.E.; Jensen, C.R. Effects of partial root-zone drying on yield, tuber size and water use efficiency in potato under field conditions. Field Crop. Res. 2007, 100, 117-124. [CrossRef]

47. Shackel, K.A.; Ahmadi, H.; Biasi, W. Plant water status as an index of irrigation need in deciduous fruit trees. Hortric. Technol. 1997, 7, 23-29. [CrossRef]

48. Enciso, J.; Sauls, J.; Wiedenfeld, B.; Nelson, S. Irrigation of Citrus in Texas-A Review. Subtrop. Plant Sci. 2005, 57, 16-22.

49. Hutton, R.J.; Loveys, B.R. A partial root zone drying irrigation strategy for citrus effects on water use efficiency and fruit characteristics. Agric. Water Manag. 2011, 98, 1485-1496. [CrossRef]

50. Flowers, T.J. Improving crop salt tolerance. J. Exp. Bot. 2004, 55, 307-319. [CrossRef] [PubMed]

51. Brumos, J.; Colmenero-Flores, J.M.; Conesa, A.; Izquierdo, P.; Sanchez, G.; Iglesias, D.J.; López-Climent, M.F.; Gómez-Cadenas, A.; Talón, M. Membrane transporters and carbon metabolism implicated in chloride homeostasis differentiate salt stress responses in tolerant and sensitive Citrus rootstocks. Funct. Integr. Genom. 2009, 9, 293-309. [CrossRef] [PubMed]

52. Byrt, C.S.; Munns, R. Living with salinity. New Phytol. 2008, 179, 903-905. [CrossRef]

53. Storey, R.; Walker, R. Citrus and salinity. Scientia Hortric. 1998, 78, 39-81. [CrossRef]

54. Maas, E.V. Salinity and citriculture. Tree Physiol. 1993, 12, 195-216. [CrossRef] [PubMed]

55. Bernstein, L. Effects of salinity and sodicity on plant growth. Ann. Rev. Phytopathol. 1975, 13, 295-312. [CrossRef] 